\title{
Loch Ness Monsters as Cryptid (Presently Unknown) Sea Turtles
}

\author{
Hen Ry H. Bauer \\ 207 Woods Edge Court, Blacksburg, VA, USA 24060-4015 \\ hhbauer@vt.edu \\ Submitted November 6, 2019; Accepted January 8, 2020; Published March 30, 2020 \\ https://doi.org/10.31275/2020/1713 \\ Creative Commons License CC-BY-NC
}

Abstract-The most popular attribution of identity for Loch Ness Monsters is a relationship with the extinct plesiosaurs, but this is difficult to square with the rarity of surface sightings let alone occasional sightings on land. On the other hand, everything described for Loch Ness Monsters is known among the many species of living as well as thought-to-be extinct turtles: air-breathing but spending very long periods in deep water; ventures onto land; very fast movement in water; ability to be active in very cold water; relatively long necks. It is suggested that Loch Ness Monsters, Nessies, are a yet-to-be-properly discovered and described variety of large sea turtle that is most likely also still extant in some specific niches in the oceans.

Keywords: Loch Ness Monsters as sea turtles-Nessies as sea turtles

\section{INTRODUCTION}

The claim that the fabled Loch Ness Monster ("Nessie") is real arouses well-founded skepticism, which in some quarters is vigorously expressed and promulgated as sheer disbelief. That is understandable since the various pieces of evidence about these creatures seem incongruous, sometimes mutually incompatible. Thus all the eyewitness reports as well as some photographs seem to describe air-breathers. On the other hand, they are seen at the surface with extraordinary rarity. Several dedicated Nessie hunters have spent a couple of decades without repeating their sole sighting of a Nessie. As Adrian Shine once 
remarked, surface watching for Nessies amounts to waging a war of attrition against the laws of chance.

And yet the cumulative record of eyewitness reports over the centuries can hardly be dismissed; see for example the descriptions gathered by Rupert Gould (1934) in the first systematic modern survey, or the testimony by Constance Whyte (1957) on first-hand acquaintance with dozens of eyewitnesses.

But then again, insisting that so many eyewitnesses could not all be mistaken might well bring a cynically skeptical response asking whether the same deference to eyewitnesses should be granted to those individuals who have claimed-at least three dozen times over the years (Watson, 2018) - to have seen one of these creatures on land.

The iconic representation of a Nessie is the rather graceful long neck and small head of the 1934 "Surgeon's" photograph. That, and Rupert Gould's conclusion long ago that Nessie is a trapped seaserpent, made it popular to regard Nessies as related to the longnecked plesiosaurs. Here it will be argued, to the contrary, that much of the apparent self-contradictions or impossible conundrums in the claimed evidence resolve when Nessies are viewed as related to sea turtles rather than to plesiosaurs.

\section{USUALLY BELOW THE SURFACE}

Nessies seem to spend much time at considerable depths. As far back as 1968, a team from Birmingham University had recorded sonar echoes from objects rising from and returning toward the bottom of the Loch (Braithwaite, 1968). Again, most sonar contacts with large single targets (not fish shoals) made by the Loch Ness \& Morar Project (2003) were deeper than about $60 \mathrm{~m}$, including a dive at appreciable speed from 69 $\mathrm{m}$ to below $100 \mathrm{~m}$.

Many species of turtle are able to spend considerable time at considerable depths, whereas plesiosaurs were active at the surface. Leatherback turtles can dive to 4,000 feet and more, comparable to whales (Spotila, 2004, p. 197). Loggerheads sometimes feed at ocean bottoms at depths of 650 feet or so (Spotila, 2004, p. 172). Physiological adaptations protect sea turtles against "the bends" that endanger deepdiving humans (Spotila, 2004, p. 43). 


\section{YET AIR-BREATHING}

Sea turtles cannot breathe underwater, but they can hold their breath for long periods of time-between 4 to 7 hours when resting. While holding their breath, their heart rate slows significantly to conserve oxygen-up to nine minutes can

pass between heartbeats. Because of this, sea turtles can stay underwater for an extended period of time when not stressed. ... Unlike the other species of sea turtles, leatherbacks have a flexible shell that absorbs nitrogen and collapsible lungs that allow them to compress themselves while diving to cope with the pressure change. The turtles have large stores of oxygen in their blood and muscles and a drastically slowed heart rate to conserve oxygen while diving. (Bennett, 2018)

Turtles breathe air; they need to come to the surface to breathe oxygen. But they have adaptations that allow them to stay underwater for long periods of time. They even have an adaptation to absorb small amounts of oxygen without breathing. ... Some species of turtles can absorb oxygen from the water, allowing them to stay underwater for long periods of time without coming up for air. The length of time they can stay underwater depends on species and temperature. Sea turtles, for example, can remain underwater for four to seven hours at rest. Hibernating turtles can stay underwater for several months. ... The cloaca is an opening in a turtle's rear end where the rectum and urinary systems empty. Expanding and contracting muscles forces water in and out of the cloaca. In some turtle species, such as the eastern painted turtle, the cloaca has a high density of blood vessels, allowing the turtle to absorb oxygen from the water through the skin. Some species, such as the musk turtle, can absorb oxygen into the blood vessels in the throat cavity. . . . While in hibernation, they don't move and their heart rates slow. They 'breathe' anaerobically, using fats stored during the summer months. This process maintains the turtles' low metabolism and cell function but results in buildup of lactic acid. The turtles' shells 
release carbonates into their systems, neutralizing the acid and preventing it from becoming deadly. (Malone, 2016)

When turtles hibernate, they rely on stored energy and uptake oxygen from the ... water by moving it across body surfaces that are flush with blood vessels. In this way, they can get enough oxygen to support their minimal needs without using their lungs. Turtles have one area that is especially well-vascularizedtheir butts. . . . turtles really can breathe through their butts. (The technical term is cloacal respiration.) (Litzgus, 2017)

"In winter they can even hibernate in the mud" off Florida and Mexico (Spotila, 2004, p. 42). In the depths of Loch Ness ( 700 feet), the oxygen level is $80 \%$ of saturation, ${ }^{(1)}$ evidently a welcoming environment for inactive or hibernating turtles.

\section{FAST-MOVING AT TIMES}

The hump filmed by Dinsdale ${ }^{2}$ moved at 7-10 mph. Leatherback turtles typically swim at up to 6-7 $\mathrm{mph}$, but a leatherback turtle was seen to move at $22 \mathrm{mph}$ when chased. ${ }^{3}$

\section{LOCH NESS IS TOO COLD FOR REPTILES}

Leatherback turtles generate heat through muscular activity, and a high ratio of mass-to-surface area allows them to retain heat even in cold water. Mackal (1976, pp. 312-313) reports experiments in which a leatherback turtle kept a body temperature of $78^{\circ} \mathrm{F}$ in water at $46^{\circ} \mathrm{F}$. Similarly, Spotila (2004, pp. 205-206) notes that leatherbacks maintained body temperatures of $60-78^{\circ} \mathrm{F}$ off Nova Scotia and Newfoundland in water at $40^{\circ} \mathrm{F}$.

\section{THERE ISN'T ENOUGH FOOD FOR A MINIMUM VIABLE POPULATION}

Roland Watson (2012) has discussed the food problem in elaborate detail. There is no precise actual knowledge about the sizes of the populations of potential prey for Nessies: 
- arctic char, estimated in 2 studies as totaling 17-24 tonnes of biomass

- eels, present in huge numbers, say 50 tonnes

- salmon, perhaps 80 tonnes at any given time, estimated from river counts and several other sources

— sea trout, estimated along similar lines at about 20 tonnes

Watson discusses a variety of pertinent points, and concludes that "there is enough food in Loch Ness to viably sustain a number of large and unknown creatures."

That raises the question, exactly what number? What is the smallest number of Nessies that could have sustained a viable continuing population since Loch Ness was cut off from the ocean as the land rose after the last Ice Age, i.e. for something like 10,000-12,000 years?

What constitutes a minimum viable population (MVP) is of contemporary concern to ecologists and conservationists, and there is no agreement on any general formula applicable to different species (Brook et al., 2011). One factor is the desirability of maintaining genetic diversity as a safeguard against catastrophic losses of population, but the Florida panther survived after only 6 had remained at one point in time (Brahic, 2008); the African cheetah shows very low genetic diversity owing, presumably, to a population bottleneck perhaps 10,000 years ago (Menotti-Raymond \& O'Brien, 1993); the northern elephant seal recovered to about 30,000 from only about 20 individuals at the end of the 19th century. ${ }^{4}$ There are many other examples, but the point is that parameters that determine the MVP are specific to each species. For Nessies, it is surely pertinent that the environment has been fairly stable since the Loch was cut off from the seas, and that Nessies are in no danger from other aquatic predators; they rule the roost.

\section{NESSIE ON LAND}

Considerably embarrassing for Nessie fans are a variety of reports from people who have seen an unidentified creature on land in the vicinity of Loch Ness. One of these reports, from Mr. and Mrs. George Spicer, has been a prominent part of the story from the very beginning, in the 1930s, of global fascination with the Loch Ness Monster. The Spicers 
described a massive creature with a long neck crossing the road ahead of their car. Estimated distances and sizes vary in different published accounts of what they reported, but none seem to describe any known creature. The same problem applies to another well-known sighting reported at that time, of a creature taking two great leaps across the road and into the loch in front of the veterinary student Arthur Grant as he was riding a motorcycle on a bright moonlit night.

Roland Watson (2018) has discussed these reports in great detail as well as listing another 30 or so claimed land sightings from the late 19th century up to the present. One can only hope that the majority of these are misidentifications of deer, cows, otters, or other known creatures, because what the eyewitnesses described in most cases is too far-out incredible, for instance shaggy creatures, several times compared to camels, in at least one case encountered at a considerable distance from the waters of Loch Ness.

One reported land sighting, however, cannot be readily dismissed as a misidentification. Torquil McLeod observed through binoculars a creature with a large body, four flipper-like appendages, and a fairly long neck or tail, as it moved on the slope of a rock scree (the Horseshoe scree) on the opposite side of the Loch from McLeod. That sighting is entirely commensurate with innumerable sightings in the water that describe hump-shaped bodies, long necks, and flipper-like appendages, as also shown in the underwater photographs obtained by teams organized by Robert Rines.

Sea turtles, of course, leave the water for land to make nests in which to deposit their eggs.

\section{SIZE AND APPEARANCE}

Nessies have usually been described as large, often as much as 20 or 30 feet long or even more. Torquil McLeod estimated 45 feet using the graticule scale on his binoculars and knowing his distance from the creature, namely the width of the Loch.

The reconnaissance experts of the Royal Air Force estimated that the hump filmed by Dinsdale showed about eight feet of length above the water and likely had a cross section (including the underwater portion) of about 5 feet by 6 feet. 
Most contemporaneously extant sea turtles are not that large. Most leatherbacks, which are the biggest, tend to be between four and six feet long including the tail and the head, but there is a report of a leatherback that reached 10 feet in length. Leatherbacks are the closest living relatives of the long extinct Archelon, whose largest fossil remains measure 15 feet in length and 13 feet sideways from flipper to flipper.

In overall appearance, sea turtles are quite a good match for Nessies. However, no sea turtle has been described as having a neck as long as the four feet or more attributed to Nessies. Still, the Australian snake-necked turtle does have a neck that can extend to more than half the length of its shell; but that shell itself is only a foot or shorter in length. ${ }^{5}$

Another apparent mismatch between Nessies and turtles is the underwater photograph described as the "gargoyle head." Eyewitnesses describe Nessie's head as rather like a horse. The heads of known living turtles vary a great deal in shape, from rather snake-like to more compact as on the western pond turtle or the fairly reptilian appearance of the common snapping turtle, not to mention the really bizarre snout of the pig-nosed turtle or the Mary River turtle which sports brushes of hair on top of the head as well as a pig-like snout.

\section{NESSIES AS TURTLES}

As Constance Whyte (1957) pointed out, the only conceivable provenance of a population of Nessies is a marine species that used to visit Loch Ness when it was an arm of the sea for a time after the last Ice Age. As the land rose gradually when freed from the weight of ice, some of the animals will have been eventually trapped, and will have later adapted to the increasingly freshwater environment. Nessies are too large to be able to enter or leave the Loch through either the rivers or the canals with locks north and south.

Sea turtles inhabit every part of the Earth's waters. They vary enormously in size and head shape, and their feeding, growth, and nesting can involve entirely different habitats in different parts of the globe (Spotila, 2004). They have a physiological adaptation that excretes the excess salt they take in through living in the oceans; losing such an adaptation in fresh water seems quite plausible. 


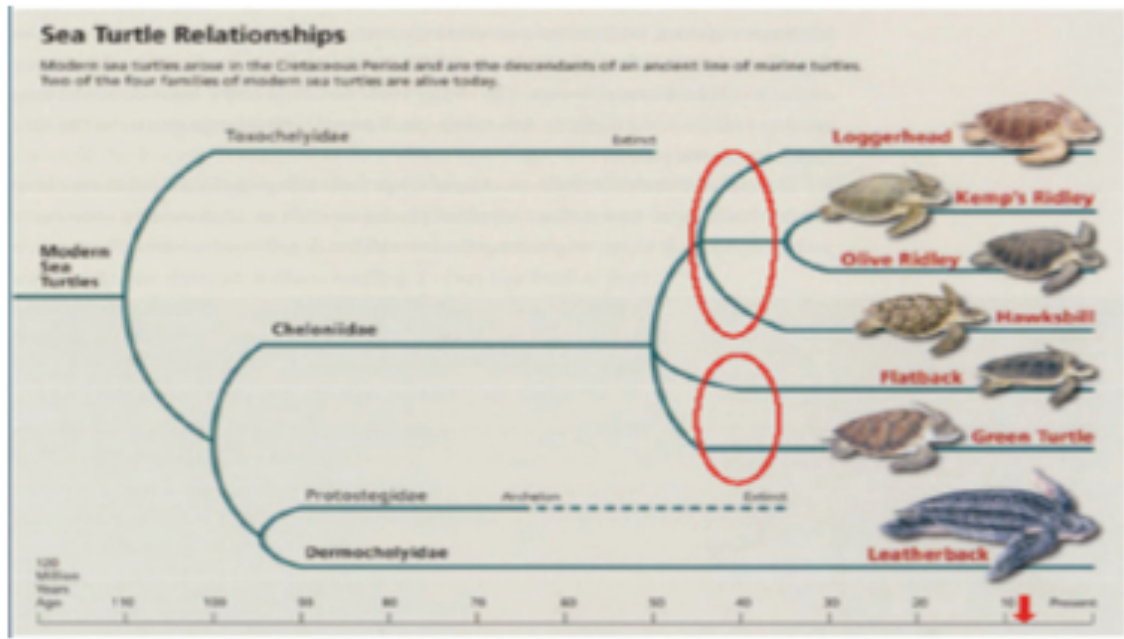

Figure 1. From The Evolution of Sea Turtles by Mike Salmon.

http://savetheseaturtle.org/The-Evolution-of-Sea-Turtles.html

But Nessies are also larger than any known living turtles, so one has to postulate a presently unknown marine species of large sea turtle; something akin to the thought-to-be extinct Archelon or some entirely unknown relative akin to Archelon and leatherbacks (Figure 1).

\section{TOWARD TESTING THE TURTLE HYPOTHESIS}

The turtle hypothesis is suggested as an attempt to circumvent difficulties faced by the popular plesiosaur hypothesis, specifically with respect to the rarity of surface sightings, the evidence of considerable time spent by Nessies at considerable depths, and reports of land sightings. Might there be ways to gather direct support for the hypothesis that Nessies are related to sea turtles?

The postulated lineage of the Cryptid Nessie Turtle was shared some 90-100 million years ago with that of the extinct Archelon and the ancestors of the still-extant leatherbacks. A major complication in seeking ways to test the hypothesis is that subsequent evolution over tens of millions of years quite likely endowed the Cryptid Nessie Turtle with behavioral characteristics not found in any now-living sea turtles. For example, a species that spends most of its time at considerable 
depths might well have evolved to deposit eggs in places of opportunity and not necessarily at sandy beaches; perhaps even directly into shallow waters; or perhaps there even evolved ovoviviparity or actual viviparity as in some snakes. Nowadays, sea turtles produce very large numbers of eggs because so many eggs and hatchlings and young turtles are lost to a host of air-, land-, and water-borne predators; perhaps the postulated Cryptid Turtle evolved a less wasteful reproductive protocol.

This is to say is that one obviously conceivable test of the turtle hypothesis, a land-based search for the remains of egg nests, could not be decisively conclusive, even apart from the general rule that absence of evidence is not evidence of absence. Nevertheless, the fact of several dozen reported land sightings (Watson, 2018) certainly makes desirable a determined, meticulous search for any signs on the shores of Loch Ness of trails or impressions of something large moving from land to water and back; there are quite a number of quite gently sloping sandy beaches on the shores of Loch Ness.

If Loch Ness was colonized not long after the last Ice Age, something like a mere 10,000-12,000 years ago, then relatives of Nessies have surely also survived to the present time in the oceans, and perhaps in other lakes as well that were formerly fjords open to the seas. Indeed, there are quite good reasons to believe that Loch Morar, very close to the West Coast of Scotland, also harbors such creatures (Campbell \& Sullivan, 1972; Magin, 2017). So one obvious test of the present hypothesis would be a sonar search for Nessies' now-living marine relatives in environments similar to what the Loch-Ness "fjord" was just after the Ice Age, in other words deep fjords (perhaps on the order of $\sim 700$ feet to be comparable to Loch Ness). A bonus would be to find promising sonar contacts in fords that also have some shallower bays or inlets or even beach-type shores. One might speculate about the periodic reports that Sweden has detected via sonar contacts in some of its fjords what it presumed were Russian submarines or minisubs, ${ }^{6}$ contacts that could not be followed to conclusive evidence and which might therefore have been sonar echoes from one of Nessie's relatives rather than a Russian submersible. Systematic sonar searches at Loch Morar also await sufficiently interested researchers with access to the considerable needed resources of equipment and expertise.

The only indisputable proof of identity, of course-indeed the only 
indisputable proof of the very existence of Nessies-is the obtaining of a living or dead specimen. Robert Rines in fact had devoted several expeditions to searching the depths of Loch Ness for the possible presence of carcasses. Such searching cries out to be continued, for there seems to be no other possible depository for dead Nessies than the floor of Loch Ness. Unfortunately, the known vast population of eels might damage carcasses to an extent that could make them exceedingly difficult to locate and identify.

During the systematic searching by the Loch Ness Investigation (LNI) in the 1960s and 1970s, some researchers hoped to obtain some Nessie tissue by means of hollow sampling darts fired from crossbows if a sufficiently close sighting ever occurred; but it did not. In 2018, however, a technique was introduced that seems potentially capable of providing similar information as would a tissue sample, namely the relatively recent methodology described as environmental DNA (eDNA). A recent documentary on the Travel Channel (USA television) describes how Professor Neil Gemmell of the University of Otago in New Zealand sampled the waters of Loch Ness in order to identify the species present there by means of the DNA in the cells that are continuously shed by all living creatures (Bauer, 2019).

Unfortunately, even this new technique cannot, at least in its present form, yield indisputably conclusive information. The gathered DNA is identified by means of the standard PCR technique, which necessitates choosing specific primers that are thought to be present, in this case primers suited to the genetic characteristics of the particular species being looked for. Gemmell was able to identify DNA from many residents of Loch Ness, in particular the large population of eels and the well-known species of fish (arctic char, trout, salmon) as well as the surprising presence of DNA from such land-based animals as deer. Insofar as possibly identifying Nessies, Gemmell was guided by the conventional wisdom as to likely candidates, and he was able to conclude that Nessies are not sturgeons or Wels catfish. The plesiosaur hypothesis was also ruled out, admittedly with less certainty owing to the need for assumptions as to what plesiosaur DNA would have been, since no authentic source of plesiosaur DNA is available. However, of the 500 million DNA samples gathered by Gemmell's team, $25 \%$ remain unidentified. The pertinent data are being made publicly available so 
that additional identifications may come in the future, and perhaps the best present hope for testing the Cryptid Turtle hypothesis is that a search will be made among the eDNA samples for genetic markers likely to be present in relatives of ancient sea turtles. Pending such specific research, this author is encouraged that the present results do not exclude that possibility (N. Gemmell, personal communication, September 29, 2019).

\section{ACKNOWLEDGMENTS}

Scott Mardis has kept me steadily au courant about plesiosaurs and other pertinent matters.

\section{NOTES}

1 According to work by Adrian Shine, cited by Roland Watson (2019).

2 The Dinsdale film can be viewed at https://www.themanwhofilmednessie.com/tims-nessie-film.html

3 http://www.euroturtle.org/suzys_faq.htm\#24

4 "Bottlenecks and founder effects", https://evolution.berkeley.edu/evolibrary/article/bottlenecks_or

5 https://nationalzoo.si.edu/animals/australian-snake-necked-turtle

6 Sweden releases mystery submarine evidence, https://www.telegraph. co.uk/news/worldnews/europe/sweden/11232820/Sweden-releasesmystery-submarine-evidence.html

\section{REFERENCES}

Bauer, H. H. (2019). Disappointing "documentary" about Loch Ness monsters ("Nessies"): (Can good documentaries be made about such subjects?). Journal of Scientific Exploration, 34(1), 105-115.

Bennett, L. (2018). Sea turtles-Cheloniidae and Dermatochelyidae. Smithsonian Institution. https://ocean.si.edu/ocean-life/reptiles/sea-turtles

Brahic, C. (2008, March 18). Florida panther population fell to just six. New Scientist. https://www.newscientist.com/article/dn13490-florida-panther-populationfell-to-just-six/\#ixzz63lu4AhD4

Braithwaite, H. (1968, December 19). Sonar picks up stirrings in Loch Ness. New Scientist, 19 December, 664-666.

Brook, B. W., Bradshaw, C. J., Traill, L. W., \& Frankham, R. (2011, December). Minimum viable population size: Not magic, but necessary. Trends in 
Ecology a Evolution, 26(12), 619-620.

Campbell, E. M., \& Solomon, D. J. (1972). The search for Morag. Tom Stacey.

Gould, R. T. (1934). The Loch Ness Monster and others. Geoffrey Bles. Reprinted in 1969 by University Books.

Litzgus, J. (2017, November 25). The secret to turtle hibernation: Butt-breathing. Live Science. https://www.livescience.com/61018-turtles-breathe-throughbutt.html

Loch Ness \& Morar Project. (2003). Loch Ness Project Report. The Loch Ness \& Morar Project, Loch Ness Centre, Drumnadrochit, Inverness-shire, Scotland.

Mackal, R. P. (1976). The monsters of Loch Ness. Swallow.

Magin, U. (2017, March 9). Early reports about Morag the monster of Loch Morar. Loch Ness Monster. http://lochnessmystery.blogspot.com/2017/03/earlyreports-about-morag-monster-of.html

Malone, M. (2016). How do turtles breathe under water? Cuteness. https://www.cuteness.com/article/do-turtles-breathe-under-water

Menotti-Raymond, M., \& O’Brien, S. J. (1993, April 15). Dating the genetic bottleneck of the African cheetah. Proceedings of the National Academy of Science USA, 9o(8), 3172-3176. https://doi.org/10.1073/pnas.90.8.3172

Spotila, J. R. (2004). Sea turtles: A complete guide to their biology, behavior, and conservation. Johns Hopkins University Press.

Watson, R. H. (2012, February 12). Is there enough food for Nessie? https:// lochnessmystery.blogspot.com/2012/02/is-there-enough-food-fornessie_12.html

Watson, R. H. (2018, March 1). When monsters come ashore: Stories of the Loch Ness Monster on land. http://lochnessmystery.blogspot.com/2018/03/a-newbook-on-loch-ness-monster.html

Watson, R. H. (2019, October 13). Looking back on the eDNA results. Loch Ness Monster. http://lochnessmystery.blogspot.com/2019/10/looking-back-onedna-results.html

Whyte, C. (1957). More than a legend: The Story of the Loch Ness Monster. Hamish Hamilton. 